ISSN 0258-7122

Bangladesh J. Agril. Res. 38(3): 389-399, September 2013

\title{
FISH-PADDY CROP ROTATION PRACTICE IN SOUTH- WEST COASTAL REGION OF BANGLADESH: A PROFITABLE TECHNOLOGY FOR THE POOR FARMERS
}

\author{
ANUPAM KUMAR ROY ${ }^{2}$, ALOKESH KUMAR GHOSH ${ }^{1}$ \\ SHEIKH TAREQ ARAFAT ${ }^{2}$ AND KHANDAKER ANISUL HUQ ${ }^{3}$
}

\begin{abstract}
The study was conducted at the farmer's pond at Sadar Upazilla of Bagerhat District, South-west coastal region of Bangladesh during the period from May 2006 to April 2007 to understand the present status of crop rotation practice and assess the production and cost benefit ratio of the existing culture practices. Two treatments viz., the crop rotation with paddy $\left(\mathrm{T}_{1}\right)$ and the shrimp-prawn-fish culture $\left(\mathrm{T}_{2}\right)$ were used in the studies. Shrimp (Penaeus monodon), prawn (Macrobrachium rosenbergii), and catla (Catla catla) were stocked at 20000, 10000, and 250 individuals/ha, respectively, in both treatments. In $\mathrm{T}_{1}$, aquaculture phase was from May to December 2006, and the episode of paddy (BRRI dhan 28) cultivation was initiated after full harvest of aqua products and continued till April. Similar farm inputs were given for the common components in both the treatments. Shrimps were harvested four months following stocking in both $\mathrm{T}_{1}$ and $\mathrm{T}_{2}$ treatments. In $\mathrm{T}_{1}$, production of shrimp, prawn, and catla were $347.20,355.35$, and $140.4 \mathrm{~kg} / \mathrm{ha}$, respectively and in $\mathrm{T}_{2}$, productions were $354.38,432.37$, and $204.7 \mathrm{~kg} / \mathrm{ha}$, respectively. In $\mathrm{T}_{1}$, total paddy production was $6200 \mathrm{~kg} / \mathrm{ha}$. Net benefit in $\mathrm{T}_{1}$ and $\mathrm{T}_{2}$ was Tk. 300,477 and Tk. 262,561/ha, respectively.
\end{abstract}

Keywords: Crop rotation, shrimp, prawn, fish production, economics.

\section{Introduction}

Bangladesh is an agro-fisheries oriented country. Fishes play an important role in the economy of many developing countries like Bangladesh and it contributes $63 \%$ of the nation's animal protein intake, about $5.6 \%$ to the GDP and more than $12.5 \%$ of the export earnings (Mazid, 2002). Rice is cultivated in about 10 million ha, which is about $75 \%$ of the country's total cropped area. There are 3 types of rice cultured in our country Aus, Aman, and Boro. Total production of these rice are 18.8 million mt. (Banglapedia, 2003). The natural environment and climate of southwest coastal region in Bangladesh is favourable for fish paddy crop rotation. This region is a charming place for the combination of all types of water, such as fresh, brackish, and marine water.

\footnotetext{
${ }^{1}$ Assistant Professor, Fisheries and Marine Resource Technology Discipline, Khulna University, ${ }^{2}$ M. S Student, Fisheries and Marine Resource Technology Discipline, Khulna University, ${ }^{3}$ Professor, Fisheries and Marine Resource Technology Discipline, Khulna University, Khulna, Bangladesh.
} 
Riverine giant prawn (Macrobrachium rosenbergii) and giant tiger shrimp (Penaeus monodon) can tolerate a certain range of salinity. The level of salinity decreases up to zero during the rainy season (July-September) and increases the during dry season (November-May) in this region. Catla (Catla catla) was cultured with shrimp to keep environment friendly reducing phytoplankton bloom. The paddy cultivated BRRI 28 can tolerate a narrow range of salinity (about 5 ppt). Crop rotation means cultivating different crops by turns which are developed for unproductive soils as well as better utilization of land. In the view of fish culture, it means culturing several types of species one after another as considering their life cycle (Gupta and Mazid, 1993) which allows mutual and beneficial biological effects on culture of different types.

Bagerhat District is the most productive zone for crop rotation. About 25,000-31,000 ha land of Bagerhat District is used alternatively for fish and paddy culture. The cultivable land is shrinking day by day for new settlements and physical infrastructures. Therefore, it is important to search more water areas for producing more fish. There is a less chance of disease outbreak in crop rotation rather than the year round fish culture system (Paul, 2000). Single crop production over the year in the same field may reduce the fertility of the soil and accumulate harmful nutrients in the pond bottom. Cultivable land reduction, seasonal inundation, and disease problems can be minimized by adopting fish paddy crop rotation. In this system, the fish excreta, unutilized feed and the residual fertilizers increased the fertility of the soil and improved paddy production. On the other hand, stumps of harvested paddy and the ploughing of the soil help increase the productivity of water and can enhance fish production. Fish-paddy rotational system allows paddy plants to absorb harmful nutrients as its manure. Thus the aim of the study was to understand the present status of crop rotation practice in Bagerhat District and assess the production and cost benefit ratio of the existing culture practices.

\section{Materials and Method}

The study was conducted in the farmer's ponds at Sadar Upazila of Bagerhat District, south-west coastal region of Bangladesh about $160 \mathrm{~km}$ north upward from the Bay of Bengal for a period of 12 months from May 2006 to April 2007. The water of this region is slightly saline because of daily tidal fluctuation of reverine water which allows different types of culture practices, such as monoculture, polyculture, integrated culture, and crop rotation. The size of the ponds varied from 0.75 to 1.5 hectares. Two types of fish culture that is polyculture and crop rotation (fish-paddy) were practiced in this region. In crop rotation system, the residue of one crop are used as fertilizer and feed for another crop, which reduces the input cost of the venture at a significant extent. 
The experiment was designed with two treatments, the crop rotation with paddy $\left(\mathrm{T}_{1}\right)$ and the shrimp-prawn-fish culture $\left(\mathrm{T}_{2}\right)$. During pond preparation, both treatments were fully dried and ploughed followed by liming and fertilization. In $\mathrm{T}_{1}$, limestone, TSP, and cowdung were used as 120,50 , and $200 \mathrm{~kg} / \mathrm{ha}$, respectively, and in $T_{2}$, it was 240,120 , and $420 \mathrm{~kg} / \mathrm{ha}$, respectively. Before stocking of fry, urea $10 \mathrm{~kg}$, TSP $5 \mathrm{~kg}$, and cowdung $20 \mathrm{~kg} / \mathrm{ha}$ were used in noncrop rotation ponds after watering but not used in crop rotation ponds. In $T_{1}$, fish was cultured from May-November and paddy was cultured from December to April. In $\mathrm{T}_{2}$, shrimp-prawn-fish culture was carried out from May to April. In both, treatments, shrimp (Penaeus monodon), prawn (Macrobrachium rosenbergii), and catla (Catla catla) were cultured and the stocking density of every species was same in both $T_{1}$ and $T_{2}$ treatments. Species-wise stocking density in $T_{1}$ and $T_{2}$ treatments are shown in Table 1.

Table 1. Species -wise stocking density and culture period in $\mathbf{T}_{\mathbf{1}}$ and $\mathbf{T}_{2}$.

\begin{tabular}{l|cc|c|c}
\hline \multirow{2}{*}{\multicolumn{1}{c|}{ Items }} & \multicolumn{2}{c|}{$\begin{array}{c}\text { Stocking density } \\
\text { (no. of individuals/ha) }\end{array}$} & \multicolumn{2}{c}{ Culture period } \\
\cline { 2 - 5 } & $\mathrm{T}_{1}$ & $\mathrm{~T}_{2}$ & $\mathrm{~T}_{1}$ & $\mathrm{~T}_{2}$ \\
\hline Penaeus monodon & 20000 & 20000 & May-September & May-September \\
Macrobrachium rosenbergii & 10000 & 10000 & May-December & May-March \\
Catla catla & 250 & 250 & May-December & May- March \\
Paddy (BRRI dhan 28) & & & December-April \\
\hline
\end{tabular}

In $\mathrm{T}_{1}$ culture period for shrimp was five months from May to September; prawn and catla were cultured for seven months from May to December; and paddy was cultured from December to April. In $\mathrm{T}_{2}$, shrimp was cultured from May-September; prawn and catla were cultured from May to March. During the month of May, after seven days of watering shrimp, prawn, and catla fry were stocked in the ponds at the density of 20000, 1000, and 250 individuals/ha, respectively. For both treatments, shrimp and catla fry were collected from hatchery and prawn was collected from natural source. In both treatments urea, TSP and cowdung were used 4, 2, and $50 \mathrm{~kg} / \mathrm{ha} /$ day, respectively, up to first 30 days of stocking. After stocking, pellet feeds (Sunny, starter-1 and 2) were used for the first two weeks at the rate of $10 \%$ of their body weight. Fish meal $(30 \%)$, mustard oil cake (20\%), wheat bran (25\%), rice bran (25\%) were used at the rate of $500 \mathrm{~g} / \mathrm{ha} /$ day for the third week after stocking at the rate of $9 \%$ of body weight. With hand made feed, artificial pellet was used and the amount was 5\% of body weight after one month up to third month. After three months, the amount was decreased to $3 \%$ of body weight up to last. Feeding was stopped in case of 
excessive rainfall and at the time of sampling. The important hydrographical parameters, such as temperature, dissolved oxygen, $\mathrm{pH}$, salinity, and transparency were monitored monthly using standard method. The water level was maintained by pump machine from the river. The weight of shrimp, prawn, and catla were monitored and recorded monthly through random sampling method. The number of samples were 50. In $T_{1}$, harvesting was completed for shrimp within September and for prawn and catla within December. The survival rate was determined by harvesting all fishes. Within one week, subsequent to harvesting of fishes from $T_{1}$, the ponds' area were prepared for paddy plantation by ploughing and $50 \mathrm{~kg} \mathrm{TSP} / \mathrm{ha}$ was used before transplantation of Boro paddy (BRRI dhan 28). Seeds of paddy were sown in November for raising seedlings. The seedlings were transplanted in $23 \times 23 \mathrm{~cm}$ distance in rows and columns. After 15 days of transplantation, $25 \mathrm{~kg}$ urea/ha was used and again after 45 days, $90 \mathrm{~kg} / \mathrm{ha}$ was used. In paddy production, no pesticide was used. Pest was controlled by Integrated Pest Management (IPM) method. The paddy culture period was about four and a half months. In non-crop rotation ponds $\left(\mathrm{T}_{2}\right)$, shrimp was harvested within September and prawn and catla were harvested within March.

\section{Results and Discussion}

\section{Hydrological parameters}

During the study period, monthly water temperature at the experimental ponds varied from 19.13 to $33.40{ }^{\circ} \mathrm{C}$. The lowest and the highest average water temperature were recorded during the period of January and June, respectively. Ali et al. (1982) stated that 20.5 to $36.5^{\circ} \mathrm{C}$ temperature is favourable for fish culture. Ali (1990) reported that the suitable water temperature in the rice fields ranged from 27 to $40^{\circ} \mathrm{C}$.

Table 2. Hydrological parameters of the studied ponds.

\begin{tabular}{l|c|c|c|c}
\hline \multirow{2}{*}{\multicolumn{1}{c}{ Parameters }} & \multicolumn{2}{|c|}{$\mathrm{T}_{1}$} & \multicolumn{2}{c}{$\mathrm{T}_{2}$} \\
\cline { 2 - 5 } & $\begin{array}{c}\text { Minimum } \\
\text { Value }\end{array}$ & Maximum Value & Minimum Value & $\begin{array}{c}\text { Maximum } \\
\text { Value }\end{array}$ \\
\hline Temperature $\left({ }^{\circ} \mathrm{C}\right)$ & 19.3 & 33.40 & 19.13 & 32.90 \\
DO $(\mathrm{mg} / \mathrm{L})$ & 5.65 & 6.89 & 5.56 & 6.70 \\
$\mathrm{pH}$ & 7.0 & 8.5 & 6.9 & 8.6 \\
Salinity $(\mathrm{ppt})$ & 0.5 & 13 & 0.5 & 8 \\
Transparency $(\mathrm{cm})$ & 28 & 38 & 26 & 37 \\
\hline
\end{tabular}

The monthly average dissolved oxygen level (DO) at the experimental ponds varied from 5.56 to $6.89 \mathrm{mg} / \mathrm{L}$ (Table 2). The highest and the lowest average DO 
was recorded during the period of November and September, respectively. Banergee (1967) reported $7.0 \mathrm{mg} / \mathrm{L}$ of dissolved oxygen of water body is good for productivity whereas the range from 3.0 to $5.0 \mathrm{mg} / \mathrm{L}$ is unproductive for fish culture. The monthly average $\mathrm{pH}$ at the experimental ponds varied from 6.9 to 8.6 (Table 2). The highest and the lowest average $\mathrm{pH}$ was recorded during the period of December and July, respectively. The monthly average $\mathrm{pH}$ at the experimental ponds ranged from 6.9 to 8.6 (Table 2). The best range of water $\mathrm{pH}$ for coastal aquaculture is 7-9 (Boyd and Fast, 1992). Ghosh (1992) opined that $\mathrm{pH}$ of water in the rice field ranging from 7.1 to 8.0 is within productive level.

The monthly average salinity at the experimental ponds varied from 0.5 to 13 ppt (Table 2). The highest and the lowest average salinity was recorded during the period of May and July, respectively. Fluctuations in salinity below 8 ppt. or above $18 \mathrm{ppt}$. has been reported to retard the growth of penaeid shrimp (Boyd and Fast, 1992).

The monthly average transparency at the experimental ponds varied from 26 to $38 \mathrm{~cm}$ (Table 2). The highest and the lowest average transparency was recorded during the period of October and January, respectively. Saha and Sinha (1969) recorded the highest value of transparency during August and September due to increased rainfall.

\section{Growth}

After 120 days of culture period, the average final body weights of shrimp in $\mathrm{T}_{1}$ and $\mathrm{T}_{2}$ were 26.4 and $27.2 \mathrm{~g}$, respectively (Fig. 1). Hossain et al. (1992) found the final body weight of $21.65 \mathrm{~g}$ for 120 days culture of shrimp where hand made feeds were used and stocking density was $30,000 /$ ha and the culture system was improved extensively. So, results of the present study are satisfactory compared to reports of the study quoted above. Hoq et al. (1994) reported a weight gain of $27.99 \mathrm{~g}$ in 105 days with a stocking density of $4 \mathrm{PL} / \mathrm{m}^{2}$. They used both hand made and pellet feeds and the culture system was improved extensively. After six months of culture period in the ponds of $\mathrm{T}_{1}$ and 8 months culture period in the ponds of $\mathrm{T}_{2}$, the average final body weights of prawn were 52 and $64 \mathrm{~g}$, respectively (Fig. 2). Shafi and Quddus (1973) found the final body weight $50.25 \mathrm{~g}$ for 180 days culture period of prawn. They used hand made feeds and stocking density was $15,000 /$ ha and the culture system was improved extensively. At the same time, average final body weights of catla in $T_{1}$ and $T_{2}$ were 780 and $1150 \mathrm{~g}$ respectively (Fig. 3). Lakshmanan et al. (1967) found the final body weight $1100.20 \mathrm{~g}$, for 240 days culture of catla. He used hand made feeds and the culture system was improved extensively which coincides the present study 
findings. Fish growth was better in $T_{2}$ than $T_{1}$ due to more supplementary feed and fertilizer utilization.

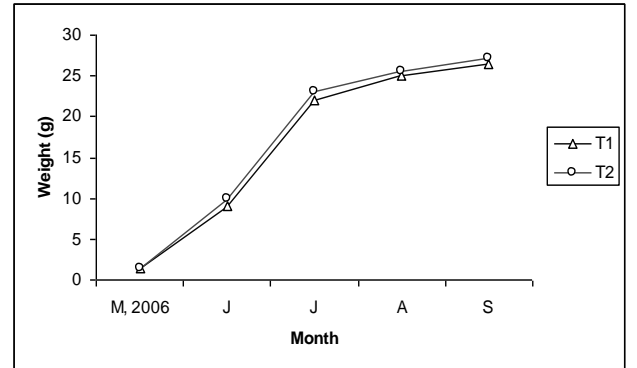

Fig.1. Monthly growth of Penaeus monodon by wt ( $\mathrm{g}$ ) in $\mathrm{T}_{1}$ and $\mathrm{T}_{2}$

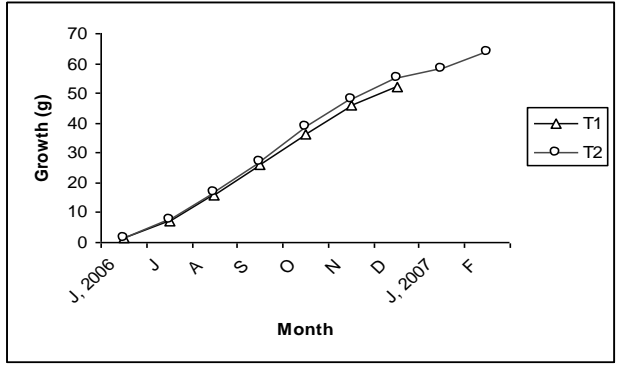

Fig.2. Monthly growth of Macrobrachium rosenbergii by wt $(\mathrm{g})$ in $\mathrm{T}_{1}$ and $\mathrm{T}_{2}$

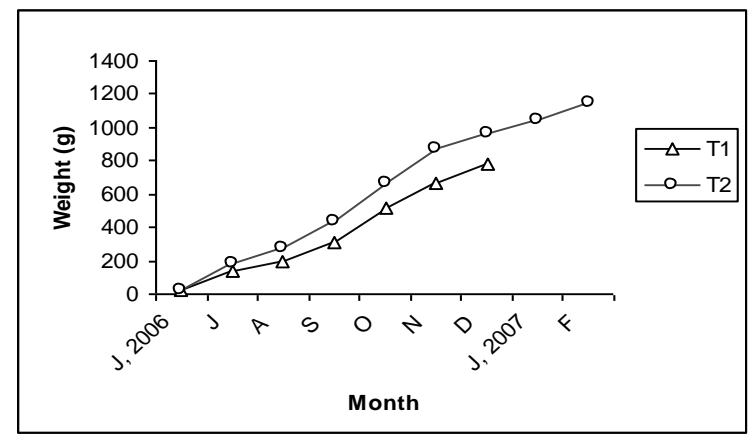

Fig. 3. Monthly growth of Catla catla in $\mathrm{T}_{1}$ and $\mathrm{T}_{2}$

\section{Survival rate}

Average survival rate of $P$. monodon in all the ponds under $\mathrm{T}_{1}$ and $\mathrm{T}_{2}$ was $56.30 \%$ and $55.20 \%$, Macrobrachium rosenbergii was $71.35 \%$ and $69.95 \%$, and Catla catla was $75.5 \%$ and $75.20 \%$, respectively (Table 3 and 4). The survival rate of fish of crop rotation ponds is better than the fish of non- crop rotation ponds due to better environmental condition. The survival rate recorded for catla was higher than the survival rates $65-68 \%$ which was recorded by Rahman et al. (1995) at the stocking density of 5000/ha of 190 days culture period in the improved extensive culture system. Motoh (1981) found 64\% survival rate of P. monodon at the stocking density of $32,000 /$ ha of 105 days culture and the culture system was improved extensive. Results of the present study for $P$. monodon survivality is slightly distorted by the Motoh (1981) survivality. Humayun (1988) found 58$71 \%$ survivality of Macrobrachium rosenbergii, at the stocking density of $12,000 /$ ha for 185 days culture, whose range is approximately similar to the results of the present study. 


\section{Cost benefit analysis}

Total production cost in $\mathrm{T}_{1}$ including paddy production cost was $88,539 \mathrm{Tk}$./ha (Table 3 and 4). Total production cost in $\mathrm{T}_{1}$ and $\mathrm{T}_{2}$ was 74,644 and 99,884 Tk./ha.

Table 3. Total expenditure/ha for fish production in $\mathbf{T}_{\mathbf{1}}$ and $\mathbf{T}_{2}$.

\begin{tabular}{|c|c|c|c|c|c|c|}
\hline & \multirow{2}{*}{ Items } & \multirow{2}{*}{ Rate } & \multicolumn{2}{|c|}{ Amount } & \multicolumn{2}{|c|}{ Total (Tk.) } \\
\hline & & & $\mathrm{T}_{1}$ & $\mathrm{~T}_{2}$ & $\mathrm{~T}_{1}$ & $\mathrm{~T}_{2}$ \\
\hline \multicolumn{2}{|c|}{ Pond preparation } & - & - & - & 12,000 & 13,300 \\
\hline \multicolumn{2}{|l|}{ Lime } & $18 \mathrm{Tk} / \mathrm{kg}$ & $118 \mathrm{Kg}$ & $247 \mathrm{Kg}$ & 2,124 & 4,446 \\
\hline \multirow{3}{*}{ Fertilizer } & Urea & $7 \mathrm{Tk} / \mathrm{kg}$ & $10 \mathrm{~kg}$ & $35 \mathrm{~kg}$ & 70 & 245 \\
\hline & TSP & $22 \mathrm{Tk} / \mathrm{kg}$ & $57 \mathrm{~kg}$ & $140 \mathrm{~kg}$ & 1,254 & 3,080 \\
\hline & Cowdung & $4 \mathrm{Tk} / \mathrm{kg}$ & $215 \mathrm{~kg}$ & $500 \mathrm{~kg}$ & 860 & 2000 \\
\hline \multirow{3}{*}{ Fry } & Shrimp PL & $\begin{array}{l}1175 \mathrm{tk} / \\
\text { thousand }\end{array}$ & 20000 & 20000 & 23,750 & 23750 \\
\hline & Prawn PL & $\begin{array}{l}1900 \mathrm{tk} / \\
\text { thousand }\end{array}$ & 10000 & 10000 & 19,000 & 19,000 \\
\hline & Catla fry & 250 Pieces & $\begin{array}{l}4 \mathrm{Tk} / \\
\text { piece }\end{array}$ & $\begin{array}{l}4 \mathrm{Tk} / \\
\text { piece }\end{array}$ & 1000 & 1000 \\
\hline \multirow[b]{2}{*}{ Feed } & Fry feed (Sunny) & $23 \mathrm{Tk} / \mathrm{kg}$ & $28 \mathrm{~kg}$ & $57 \mathrm{~kg}$ & 644 & 1311 \\
\hline & $\begin{array}{l}\text { Grower fish (Hand } \\
\text { made) }\end{array}$ & $18 \mathrm{Tk} / \mathrm{kg}$ & $305 \mathrm{~kg}$ & $600 \mathrm{~kg}$ & 5,490 & 10,800 \\
\hline \multicolumn{2}{|c|}{ Labour cost } & $100 \mathrm{Tk} / \mathrm{man}$ & 50 men & 170 men & 5,000 & 17000 \\
\hline \multicolumn{2}{|c|}{ Harvesting } & $100 \mathrm{Tk} / \mathrm{man}$ & 35 men & 40 men & 3,500 & 4000 \\
\hline \multicolumn{2}{|l|}{ Total } & & & & 74,644 & $\mathbf{9 9 , 8 8 4}$ \\
\hline
\end{tabular}

Table 4. Total expenditure/ha for paddy production in $T_{1}$ treatment.

\begin{tabular}{lcc|c|r}
\hline \multicolumn{2}{c|}{ Items } & Rate & Amount & \multicolumn{1}{c}{ Total (Tk.) } \\
\hline \multicolumn{2}{c|}{ Land preparation } & - & - & 2,500 \\
\hline \multirow{2}{*}{ Fertilizer } & Urea & $7 \mathrm{Tk} . / \mathrm{kg}$ & $115 \mathrm{~kg}$ & 805 \\
& TSP & $22 \mathrm{Tk} . / \mathrm{kg}$ & $40 \mathrm{~kg}$ & 880 \\
Seed cost & $20 \mathrm{Tk} . / \mathrm{kg}$ & $72 \mathrm{~kg}$ & 1,440 \\
Plantation cost & $90 \mathrm{Tk} . / \mathrm{man}$ & $20 \mathrm{men}$ & 1,800 \\
Weeding cost & $90 \mathrm{Tk} . / \mathrm{man}$ & $15 \mathrm{men}$ & 1,350 \\
Watering cost & - & - & 1,520 \\
Harvesting & 90Tk./man & $40 \mathrm{men}$ & 3,600 \\
\hline \multicolumn{2}{l}{ Total } \\
\hline
\end{tabular}




\section{Fish production}

The average gross fish productions in $\mathrm{T}_{1}$ and $\mathrm{T}_{2}$ were recorded $842.95 \mathrm{~kg} / \mathrm{ha}$ and $991.45 \mathrm{~kg} / \mathrm{ha}$, respectively. The total fish production varied between the two treatments because in $T_{1}$, fish was cultured for six months and in $T_{2}$ fish was cultured for eight months. The first one is crop rotation pond. In $T_{1}$, the production of shrimp, prawn, and catla were $347.20,355.35$, and $140.4 \mathrm{~kg} / \mathrm{ha}$, respectively (Table 5, Fig. 4). Molla et al. (1986) recorded 440-480 kg/ha production of catla in six months culture period. In $\mathrm{T}_{2}$, the production of shrimp, prawn, and catla were 354.38, 432.37, and $204.7 \mathrm{~kg} / \mathrm{ha}$, respectively (Table 6). Quddus et al. (1990) recorded $585 \mathrm{~kg} / \mathrm{ha}$ shrimp through improved extensive method in 120 days culture period at the stocking density of 28,000/ha which was higher than the production of shrimp in the present study.

Table 5. Production and price of shrimp, prawn, and catla in $T_{1} /$ ha.

\begin{tabular}{|c|c|c|c|c|c|c|c|c|c|}
\hline Species & $\begin{array}{c}\text { No. } \\
\text { of } \\
\text { Fries }\end{array}$ & $\begin{array}{c}\text { No. } \\
\text { of } \\
\text { catch }\end{array}$ & $\begin{array}{l}\text { Survivality } \\
(\%)\end{array}$ & Grade & $\begin{array}{c}\text { No. of } \\
\text { individuals }\end{array}$ & $\begin{array}{c}\text { Average } \\
\text { individual } \\
\text { wt }(\mathrm{g})\end{array}$ & $\begin{array}{l}\text { Grade- } \\
\text { wise } \\
\text { production } \\
(\mathrm{kg} / \mathrm{ha})\end{array}$ & $\begin{array}{c}\text { Rate } \\
\text { (Tk./ } \\
\mathrm{kg})\end{array}$ & $\begin{array}{l}\text { Total } \\
\text { Taka }\end{array}$ \\
\hline \multirow{5}{*}{ Shrimp } & \multirow{4}{*}{20000} & \multirow{4}{*}{13371} & \multirow{4}{*}{66.8} & 66 & 1558 & 17.40 & 27.11 & 250 & $6,777.5$ \\
\hline & & & & 44 & 9352 & 24.02 & 224.64 & 350 & 78,624 \\
\hline & & & & 30 & 1886 & 35.00 & 66.01 & 450 & $29,704.5$ \\
\hline & & & & 20 & 575 & 51.20 & 29.44 & 550 & 16,192 \\
\hline & & & & & Total & & 347.20 & & $1,31,298$ \\
\hline \multirow{5}{*}{ Prawn } & \multirow{5}{*}{10000} & \multirow{4}{*}{6778} & \multirow{4}{*}{67.78} & 5 & 100 & 202 & 20.2 & 650 & 13,130 \\
\hline & & & & 10 & 579 & 103 & 59.64 & 600 & 35,784 \\
\hline & & & & 20 & 3453 & 52.20 & 180.25 & 400 & 72,100 \\
\hline & & & & 30 & 2646 & 36 & 95.26 & 300 & 28,578 \\
\hline & & & & \multicolumn{3}{|c|}{ Total } & 355.35 & \multicolumn{2}{|r|}{$1,49,592$} \\
\hline Catla & 250 & 180 & 72 & - & - & 780 & 140.4 & 65 & 9,126 \\
\hline
\end{tabular}

\section{Paddy production}

Paddy production from the crop rotation ponds of $T_{1}$ was $6200 \mathrm{~kg} / \mathrm{ha}$, which yielded the income from paddy cultivation of Tk. 93000/ha. Income from selling straw was Tk. 6000/ha. So the gross income from paddy during the culture period was Tk. $99000 / \mathrm{ha}$. The production of grain was $3400-3800 \mathrm{~kg} / \mathrm{ha}$ by Rahman et al. (1995), which was lower to the production of grain recorded in the present study. 
Table 6. Production (kg/ha) and price of shrimp, prawn, and catla in $T_{2}$.

\begin{tabular}{|c|c|c|c|c|c|c|c|c|c|}
\hline Species & $\begin{array}{l}\text { No. of } \\
\text { Fries }\end{array}$ & $\begin{array}{l}\text { No. of } \\
\text { catches }\end{array}$ & Survivality (\%) & Grade & $\begin{array}{c}\text { No. of } \\
\text { individuals }\end{array}$ & $\begin{array}{c}\text { Average } \\
\text { individual wt } \\
(\mathrm{g})\end{array}$ & $\begin{array}{c}\text { Grade- wise } \\
\text { production } \\
(\mathrm{kg} / \mathrm{ha})\end{array}$ & $\begin{array}{c}\text { Rate } \\
(\mathrm{Tk} / \mathrm{kg})\end{array}$ & Total Taka \\
\hline & & & & 66 & 1458 & 17.55 & 25.59 & 250 & 6397.50 \\
\hline \multirow[t]{5}{*}{ Shrimp } & 20000 & 13110 & 65.55 & 44 & 8702 & 24.10 & 209.72 & 350 & 73402 \\
\hline & & & & 30 & 2147 & 36.00 & 77.29 & 450 & 34780.50 \\
\hline & & & & 20 & 803 & 52.03 & 41.78 & 550 & 22979 \\
\hline & & & & & Total & & 354.38 & & 137559 \\
\hline & & & & 5 & 372 & 202.40 & 75.29 & 650 & 48938.50 \\
\hline \multirow[t]{4}{*}{ Prawn } & 10000 & 6645 & 66.45 & 10 & 1109 & 103.25 & 114.50 & 600 & 68700 \\
\hline & & & & 20 & 3467 & 52.20 & 180.98 & 400 & 72392 \\
\hline & & & & 30 & 1697 & 36.30 & 61.60 & 300 & 18480 \\
\hline & & & & & Total & & 432.37 & & 208510.5 \\
\hline Catla & 250 & 178 & 71.2 & - & - & 1150 & 204.70 & 80 & 16376 \\
\hline
\end{tabular}


Net profit from two treatments, fish-paddy crop-rotation $\left(\mathrm{T}_{1}\right)$ and only fish culture $\left(\mathrm{T}_{2}\right)$ were Tk. 3,00,477 and Tk. 2,62,561/ha, respectively (Table 7). In general, fish farming is more than $200 \%$ profitable through improved extensive system (Hoq et al., 1994). So the above statement supports the results of the present study.

Table 7. Income, production cost, and net profit in $T_{1}$ and $T_{2}$ treatments.

\begin{tabular}{|c|c|c|}
\hline \multirow{2}{*}{ Items } & \multicolumn{2}{|c|}{ Production and income (Tk./ha) } \\
\hline & $\mathrm{T}_{1}$ & $\mathrm{~T}_{2}$ \\
\hline Production cost & 88,539 & 99,884 \\
\hline Gross income & $3,89,016$ & $3,62,445.5$ \\
\hline Net profit & $3,00,477$ & $2,62,561.5$ \\
\hline
\end{tabular}

\section{Conclusion}

The fish paddy crop rotation system enhances the fertility of the ponds. It takes low investment but gives the reasonable production. The remaining part of paddy can be used as fertilizer or feed for the cultivable species, thus it can minimize the cost of fertilizer and supplementary feed. Therefore, crop rotation practice can be introduced for the poor and marginal fish farmer to reduce the investment cost. But it is not suitable for all areas. The land area with lower altitude where water exists round the year, it is difficult to culture paddy but the land that contains water for a particular time is suitable for crop rotation practice. During the period of February to June, the salinity is high so Penaeid shrimp can be cultured. During the rainy season, fresh water is increased so paddy and other fishes can be cultured easily.

\section{References}

Ali, S., A. K. A. Rahman, A. R. Patwary and K. H. R. Islam. 1982. Studies on the diurnal variations in physiochemical factors and zooplankton in a fresh water pond. Bangladesh J. Fish 2-5(1-2): 15-23.

Ali, A. B. 1990. Rice-fish farming in Malaysia: A Resource Optimization AMBIO 19: 404-408.

Banergee, S. M. 1967. Water quality and soil condition of fish ponds in some states of India in relation to fish production. Indian J. Fish. 14: 115-144.

Banglapedia. 2003. National Encyclopedia of Bangladesh. Published by Asiatic society of Bangladesh, Dhaka. 1: 67-84.

Boyd, C. E. and A.W. Fast. 1992. Pond monitoring and management. In: Marine shrimp culture: Principles and Practices. A.W. Fast and L. J. Lester (eds.). Elsevier, Amstardam. Pp. 497-508. 
Gupta, M.V. and M.A. Mazid. 1993. Feasibility and potentials for integrated rice fish systems in Bangladesh. Paper presented at twelfth session of the FAO regional farm Management Commission of Asia and the Far East, Dhaka, Bangladesh. Pp. 1-19.

Ghosh, A.N. 1992. Rice fish farming development in India: past, present and future. In: Rice-fish research and development in Asia. C.R. Cruz, C. Lightfoot, B.A CostaPrice, V.R. Carnagal and M.P. Bimbao (eds). Pp. 234-243.

Hoq, M. E., G. C. Halder and M. Begum. 1994. Experimental pond culture of tiger shrimp, Penaeus monodon (Fab.) with various stocking rates and supplemental feeding. Progress Agric. 5(2): 55-61.

Hossain, S. M. Z., J. R. V. Corre and C. E. Tolcdo. 1992. Effect of stocking densities on the growth, survival and production of Penaeus monodon (Fabricius). Bangl. J. Zoo. 20 (1): 35-42.

Humayun, N.M. 1988. Observation of the pond growth rate of Macrobrachium rosenbergii at different stocking densit. Bang. J. Zoo. 16 (2): 171-175.

Lakshmanan, M. A. V., B.R. Bhuiyan, , S. Radhakrishna, and M. Babu. 1967. Survival and growth of cultivable fishes in Assam ponds. Ind. J. Fish. 14: 1-23.

Mazid, M. A. 2002. Fisheries Resource Information of Bangladesh. In: Matsha Sapta Sankalan, Ministry of Fisheries and Livestock. Government of the People's Republic of Bangladesh. Pp. 17-18.

Molla, A. R., N. C. Biswas and M. S. Islam. 1986. An economic analysis of fish culture under different pond size. Bang. J. Aqua. 11: 99-100.

Motoh, H. 1981. Studies on the fishery biology of the giant tiger prawn, Penaeus monodon in the Philippines (Technical Report No. 7) Aquaculture Department, SEAFDEC, Tigbauan, Iioilo City, Philippines. P. 128.

Paul, H. K. 2000. A leaflet on fish disease. Bangladesh Fisheries Research Institute, Paikgacha, Khulna. Pp. 5-7.

Quddus, M. M. A., G. B. Sufi, M. A. Kalam and B. S. Nahar. 1990. Culture of Shrimp Penaeus monodon (Fab.) in a brackish water pond. Bang. J. Sci. 8(2): 153-163.

Rahman, M. A., M. V. Gopta and J. D. Sollows. 1995. Integration of aquaculture with dry season irrigated rice farming in Bangladesh. Paper presented Fourth Asian Fisheries Forum in Beijing, China. Pp. 45-49.

Saha, A. B. and B. M. Sinha. 1969. Investigation on bio-ecology of Indian waters of Gorrakhpur, India. Hydrobiology 34: 433-447.

Shafi, M. and M.M.A. Quddus. 1973. Age, growth, and food of the giant prawn, Macrobrachium rosenbergii (De Man) of Bangladesh. J. Biol. Sci. 2 (2): 3-6. 